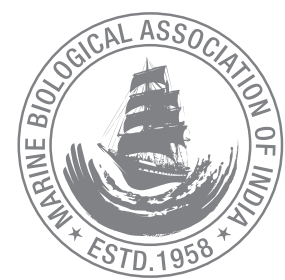

\title{
First record of the reef lobster Enoplometopus occidentalis (Randall, 1840) from Indian waters
}

\author{
E. V Radhakrishnan* and P. Jayasankar' \\ Central Marine Fisheries Research Institute, Ernakulam North P.O., Kochi- 682018 \\ ' Central Institute of Freshwater aquaculture, Bhubaneswar, Orissa. \\ *Correspondence e-mail: evrkrishnan@yahoo.com
}

Received: 21 Aug 2012, Accepted: 24 Jul 2014, Published: 15 Nov 2014

\begin{abstract}
A single specimen of the reef lobster, Enoplometopus occidentalis measuring carapace length $57.0 \mathrm{~mm}$, total length $127.0 \mathrm{~mm}$ and $46.7 \mathrm{~g}$ in weight was landed at Mandapam fish landing centre, on the southeast coast of India. The lobster was caught during the deep sea trawl fishing operations off Mandapam $\left(08^{\circ}\right.$ $58^{\prime} \mathrm{N}$ lat. $79^{\circ} 16^{\prime} \mathrm{E}$ long.). This is the first record of the species from Indian waters. The morphological characters along with colour pattern are described. The large chelae in the specimen were found missing.
\end{abstract}

Keywords: Gulf of Mannar, reef lobster, Enoplometopus occidentalis.

\section{Introduction}

Enoplometopus occidentalis also referred to as the 'Hawaiian reef lobster' or 'Hairy reef lobster' is a member of the Superfamily Enoplometopoidea Saint Laurent, 1988 and family Enoplometopidae Saint Laurent, 1988, under the order Decapoda. They were earlier considered as Nephropid lobsters of the family Nephropidae and later assigned to the Thalassinidean family of Axiidae Huxley, 1879 (Holthuis, 1974). Enoplometopus has been recognized in its own superfamily within the Astacidea by following the most robust phylogenetic analysis of decapod crustaceans by Tsang et al. (2008). Enoplometopus is the only genus recognized following Chan \& Yu (1993), Poupin (2003) and Chan \& Ng (2008). They can be distinguished from the clawed lobsters of the family Nephropidae by the presence of full claws only on the first pair of the pereiopods, the second and third pairs are subchelate. The reef lobsters have a shallow cervical groove compared to clawed lobsters in which the cervical groove is deep. So far, twelve species have been recorded under this genus, two from the Atlantic, four from the Indo-West Pacific region, two from the western Pacific, one from Philippines only, one from Philippines and India only, one from Reunion only and one from French Polynesia and Japan (Chan and Ng, 2008). They are brightly coloured inhabiting coral and rocky reefs or in the deeper part of the reef slopes at a depth of $30 \mathrm{~m}$ to $300 \mathrm{~m}$. It differs from its congeners mainly by the number of spines on the carapace, length of the chelae and presence or absence of spines on the abdominal pleura. They also vary in colour from other members of the genera in being orange-red, red, purple/or white, with conspicuous spots on the body and sometimes with stripes. E. occidentalis is probably the most common species of the genus but still 
rather rare and has ornamental value. Small specimens are occasionally found in the aquarium trade and sold at a high price. The species has a wide distribution in the Indo-West Pacific region from eastern Africa to Japan, eastern Australia and Hawaii. Enoplometopus occidentalis is reported for the first time from Indian waters.

\section{Material and methods}

A male specimen was observed in the deep sea trawl landings at the Mandapam landing centre, Tamil Nadu on the southeast coast of India. The specimen was incidentally caught on 26.6.1991 during deep sea trawling off Mandapam $\left(08^{\circ} 58^{\prime} \mathrm{N}\right.$ lat. $79^{\circ} 16^{\prime} \mathrm{E}$ long.). The first pair of chelipeds of the specimen on observation was found missing. The specimen was identified following the keys provided by Poupin (2003) and Chan and $\mathrm{Ng}$ (2008) and confirmed by Dr. Holthuis. The specimen was deposited in the Museum at the Regional Centre of the Central Marine Fisheries Research Institute, Mandapam, India.

\section{Systematics}

Enoplometopus occidentalis (Randall, 1840) [Nephrops occidentalis]

Class: Malacostraca

Order: Decapoda

Suborder: Macrura Reptantia Bouvier, 1917

Infraorder: Astacidea, Latreille, 1802

Superfamily: Enoplometopoidea Saint Laurent, 1988

Family: Enoplometopidae Saint Laurent, 1988

Genus: Enoplometopus A.Milne-Edwards, 1862

Specific name: occidentalis (Randall, 1840)

Material examined: A single male specimen from Mandapam landing centre on the southeast coast of India $\left(08^{\circ} 58^{\prime} \mathrm{N}\right.$ lat. $79^{\circ} 16^{\prime} \mathrm{E}$ long.). The specimen was measured $57.0 \mathrm{~mm}$ in carapace length, $127.0 \mathrm{~mm}$ in total length and $46.7 \mathrm{~g}$ in weight.

\section{Results and discussion}

\section{Description}

This is the first record of the species from the Indian coast (Fig.1). A characteristic feature of the genus Enoplometopus is the presence of tufts of long stiff hairs on carapace, abdomen, uropods and the pereiopods. Carapace is laterally compressed and smooth with a well developed rostrum which extends till the base of the antennal peduncle. The rostrum has four spines on the lateral margin. The carapace is with four median and one post cervical spine, which are all pointed. There are four lateral spines, two intermediate and one supra-ocular spine on the carapace. The cervical groove is not very prominent. Second to fifth pereiopods are slender. Both chelipeds were found missing. The pleura of the abdominal somites II-V rounded and blunt (Fig.2). The posterior region of the telson is convex and has one lateral median and three disto-lateral movable spines. The first pleopod of the male is leaf-like and thread-like in females. The first pair of pleopods has been modified into a copulatory organ.

\section{Colour}

The entire animal is brilliantly red in colour. The spines are red, but most having a white tip. There is a moderately large

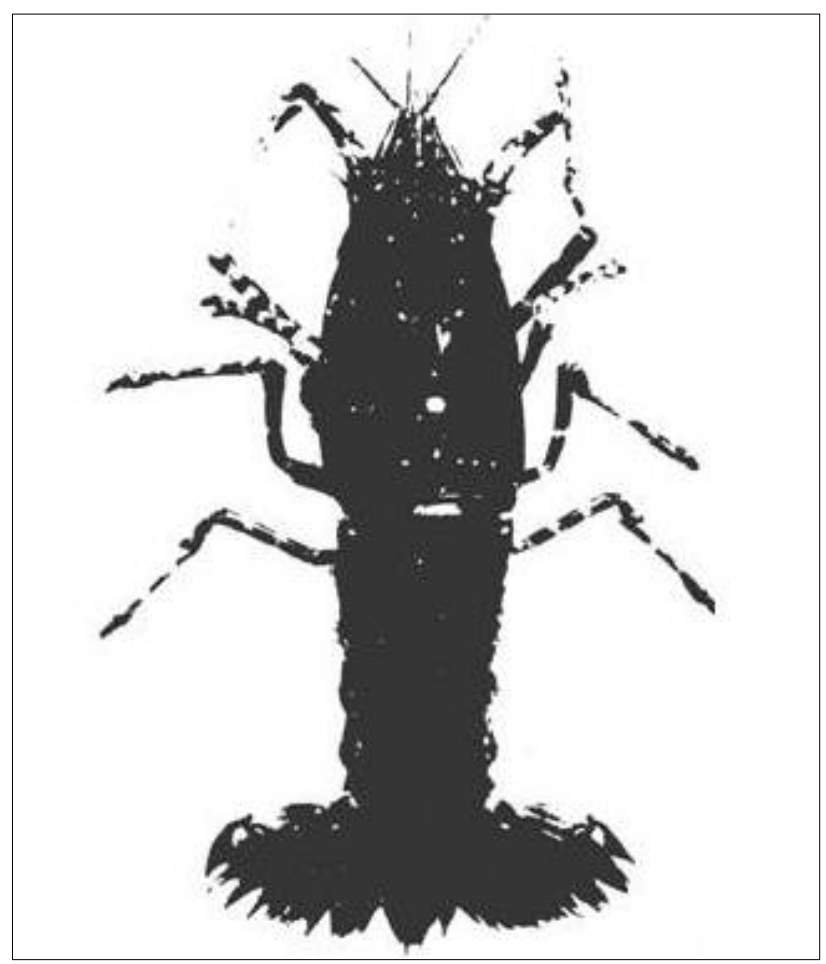

Fig. 1. Dorsal view of Enoplometopus occidentalis (Randall, 1840).

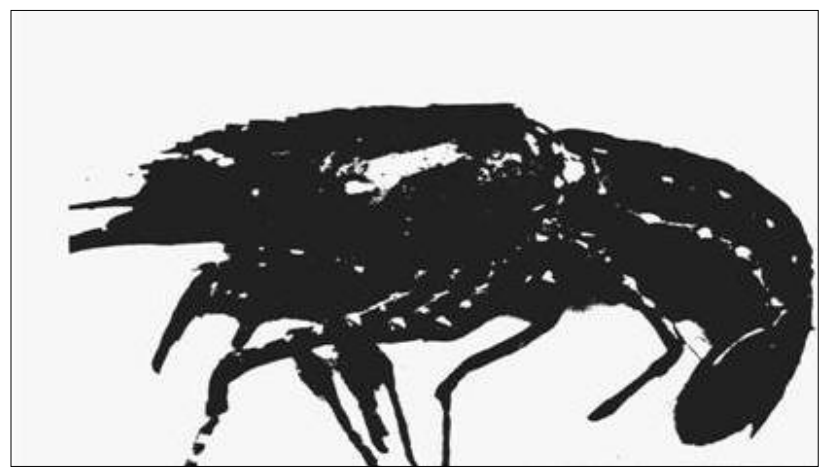

Fig. 2. Lateral view of Enoplometopus occidentalis showing the carapace and abdominal pleura 
white spot in the centre of the lateral surface of the carapace surrounded by a dark ring. Another smaller white spot surrounded by a dark red ring is seen above this. The entire lateral margin of the carapace is free of any bands. Behind the cervical spine there is a white spot. White spots are also present on the median part of the rostrum.

A large white spot is present on the pleuron of the first somite; a similar but smaller white spots are also present on the base of each of the pleura of the following somites. The pleura also have a white ocellate spot on the distal margin. The posterior margin of the tergum of the first abdominal somite has a median and at either side 2 or 3 smaller white spots. The terga of the second to fifth abdominal somites show 4 white spots at or somewhat posterior to the margin; two are submedian and two are more lateral. The flagella of the antennules are red; the antennal flagella are uniformly red, with tips of the spines white. The pereiopods are red with several narrow white bands. The uropods are red and the spines have white tips.

The distinguishing differences in morphology and colouration of $E$. occidentalis and $E$. macrodontus, the two species occurring in Indian waters, are given in Table 1.

\section{Distribution}

E.occidentalis is the most common species of the genus from the Indo-Pacific region (Holthuis, 1983). The species is distributed along Hawaii (type locality), South Africa (Natal), Kenya (Mombassa), Madagascar, Mauritius, Seychelles, (Java sea, Celebes), Moluccas, Indonesia, East Australia (Great Barrier Reef), Japan and Taiwan.
This is the first record of the species from the Indian waters, thus extending its distribution to the Indian coast. Radhakrishnan et al. (2011) reported landing of a few specimens of $E$. macrodontus from trawl landings at Ponnani, north of Cochin on the southwest coast of India and this was also the first record of the species from Indian coast. $E$. occidentalis has a wider distribution in the Indo-West Pacific region (Poupin, 2003). It was first recorded from Hawaii and later on along the West Indian Ocean, West Pacific, Central Pacific and East Australia. Other species of the genus known are E.chacei, E.crosnieri, E.daumi, E.debelius, E.gracilipes, E.holthuisi, E. macrodontus, E.pictus, E.callistus, E. volgtmanni and E.antillensis. There are four spines seen on the rostrum and Poupin (2003) stated that the number of spines on the rostrum may vary from two to four. The anterior most median spine was noted to be blunt in the specimens examined by him whereas in this specimen it is pointed. Poupin (2003) observed several variations within the fourteen specimens examined. Chan \& $\mathrm{Ng}$ (2008) has provided an identification key with distinguishing characters of each of the 12 species in the genus and opined that the spines on the large chela and margin of the abdominal tergite $\mathrm{VI}$ are key characters in identification of the species. In the present specimen though the chelipeds were missing, the specimen could be identified on the basis of other morphological characters such as spines on the carapace, telson and the shape of the pleura. All Enoplometopus species are known to have very distinctive and diagnostic colourations (Chan \& Ng, 2008) and this could be a valid species identification tool for live or newly caught specimens of this specialized group of crustaceans.

The occurrence of a single specimen of the reef dwelling species from the Indian coast is intriguing though they form a fishery in Hawaii and therefore they are known as the

Table 1. Distinguishing colours, characters and distribution of Enoplometopus macrodontus and E. occidentalis

\begin{tabular}{|c|c|c|c|c|c|c|}
\hline & \multicolumn{4}{|c|}{ Colour } & \multicolumn{2}{|r|}{ Distribution } \\
\hline & Lateral carapace & Abdomen & Antennular flagellae & $\begin{array}{l}\text { Large chelae (PI) } \\
\text { fingers }\end{array}$ & $\begin{array}{l}\text { Walking legs (P } \\
\text { II-V) }\end{array}$ & \\
\hline E.occidentalis & $\begin{array}{l}\text { only one moderate large } \\
\text { white spot }\end{array}$ & $\begin{array}{l}\text { many white spots } \\
\text { on tergites and } \\
\text { pleura }\end{array}$ & not banded & indistinctly banded & entirely banded & $\begin{array}{l}\text { Indo-west Pacific, Gulf } \\
\text { of Mannar, Southeast } \\
\text { coast of India }\end{array}$ \\
\hline \multirow[t]{3}{*}{ E. macrodontus } & $\begin{array}{l}\text { only one moderate large } \\
\text { white spot }\end{array}$ & $\begin{array}{l}\text { many white spots } \\
\text { on tergites and } \\
\text { pleura }\end{array}$ & not banded & $\begin{array}{l}\text { only with one white } \\
\text { band }\end{array}$ & $\begin{array}{l}\text { banded only at } \\
\text { basal segments }\end{array}$ & $\begin{array}{l}\text { Philippines and Ponnani, } \\
\text { South west coast of } \\
\text { India only }\end{array}$ \\
\hline & \multicolumn{6}{|c|}{ Morphological characters } \\
\hline & $\begin{array}{l}\text { carapace teeth (lateral + } \\
\text { intermediate }+ \text { median/ } \\
\text { post cervical) }\end{array}$ & $\begin{array}{l}\text { post cervical } \\
\text { tooth }\end{array}$ & Rostrum & $\begin{array}{l}\text { Maxilliped III } \\
\text { ischium distoventral } \\
\text { spine }\end{array}$ & Abdominal pleura & Telson lateral spines \\
\hline E.occidentalis & $\begin{array}{l}3+2+5 / 1, \text { anterior most } \\
\text { median tooth sometimes } \\
\text { as elevated triangular plate }\end{array}$ & Well developed & $\begin{array}{l}\text { 2-4 lateral teeth, more or } \\
\text { less to tip of antennal } \\
\text { peduncle lateral }\end{array}$ & absent & $\begin{array}{l}\text { Terminated in } \\
\text { blunt angles }\end{array}$ & one pair \\
\hline E. macrodontus & $2+1+5 / 1$ & Well developed & $\begin{array}{l}\text { 3-4 teeth over relating } \\
\text { antennal peduncle }\end{array}$ & Present & $\begin{array}{l}\text { Terminated in } \\
\text { short spines }\end{array}$ & two pairs \\
\hline
\end{tabular}

From Chan \& Ng, 2008 
Hawaiian reef lobster. Since reef lobsters are nocturnal and shy they are very difficult to be caught. E. occidentalis is traded in the aquarium industry and is a high value species.

\section{Acknowledgements}

The authors are grateful to Dr. L. B. Holthuis, the Legendary Carcinologist Rijksmuseum van Natuurlijke Historie, Leiden, Netherlands for confirming the identity of the specimen.

\section{References}

Chan, T. Y and Ng. 2008. Enoplometopus A. Milne Edwards, 1862 (Crustacea: Decapoda: Nephropoidea) from the Philippines, with description of one new species and a revised key to the genus. Bull. Mar. Sci, 83 (2): 347-365.
Chan, T. Y. and H. P. Yu 1993. The illustrated lobsters of Taiwan. SMC Publishing Inc., Taipei, Taiwan: $246 \mathrm{pp}$.

Holthuis, L. B. 1974. Biological results of the University of Miami Deep-sea Expedition 106. The lobsters of the superfamily Nephropoidea of the Atlantic Ocean (Crustacea:Decapoda). Bull. Mar. Sci., 24 (4) :723-884.

Holthuis, L. B. 1983. Notes on the genus Enoplometopus, with descriptions of a new subgenus and two new species (Crustacea: Decapoda, Axiidae). Zool. Med., 56 (22): $281-298$.

Poupin, J. 2003. Reef lobsters Enoplometopus A.Milne Edwards, 1862 from French Polynesia, with a brief revision of the genus (Crustacea, Decapoda, Enoplometopidae). Zoosystema, 25(4): 643-664.

Radhakrishnan, E.V., S. Lakshmi Pillai, Rajool Shanis and M. Radhakrishnan.2011. First record of the reef lobster Enoplometopus macrodontus Chan \& Ng, 2008 from Indian waters. J. Mar. Biol. Ass. India, 53(2): 264-267.

Tsang, L. M., K. Y. Ma, S. T. Ahyong, T. Y. Chan and K. H. Cha. 2008. Phylogeny of Decapoda using two nuclear protein coding genes, origin and evolution of the Reptantia; Mol. Phylogenet. Evol., 48: 359-368. 